\title{
Translating irony. Translation strategies and techniques used by Polish translators of Pride and Prejudice
}

\begin{abstract}
This article presents the results of a comparative analysis of two Polish translations of Pride and Prejudice by Jane Austen. The authors of the translations are Anna Przedpełska-Trzeciakowska and Magdalena Gawlik-Małkowska. Attention is given to rendering irony, which is the novel's characteristic feature. The analysed excerpts illustrate the main translation strategies and techniques used in the Polish translations. A comparative analysis shows that techniques applicable to rendering humour and culture-bound elements can be used to translate irony as well. The Polish translations convey irony, but there are differences caused by the translators' interpretations and by their choice of strategies and techniques. Przedpełska-Trzeciakowska often uses the strategy of foreignization, but she tries to guide the reader so that they can perceive the implicature. Gawlik-Małkowska's translation is more literal and more modern, and its irony is more covert.
\end{abstract}

Keywords: Jane Austen, translation, translation strategy, translation technique, literary irony.

\section{Introduction}

Many scholars dealing with translation studies agree that full equivalence between the source text (ST) and the target text (TT) can never be achieved (Munday 2010: 37, 43). The concept of equivalence appeared in the work of Vinay and Darbelnet, 'Stylistique Comparée du Français et de L'Anglais' (1958); equivalence was enumerated as one of the procedures used in translation (Vinay \& Darbelnet 1958: 8). The term was then described by Roman Jakobson (1959: 139) who wrote about the equivalence of words and meaning, and by many other scholars. For example, Baker (1992) identified various kinds of equivalence occurring on different levels: grammar, pragmatics, etc. The notion of

1 Address for correspondence: Maria-Curie Sklodowska University, Pl. M. Curie-Skłodowskiej 5, 20-031 Lublin, Poland. E-mail: magdaz3636@gmail.com 
equivalence is important while conducting a comparative analysis of translations. TT should be faithful to the original on each level and preserve its style and message. When the meaning is implicit, as in the case of irony, the task becomes more complicated.

Perceiving literary irony requires more attention from the reader than noticing the irony in someone's speech, when additional signs can be noticed, suggesting the right interpretation (tone of voice, facial expression, various gestures) (Wilson \& Sperber 2012: 123). Noticing irony in Jane Austen's novel poses additional problem: the text and its humour is dated. Pride and Prejudice was first published in 1813 and contains many caustic and bitter remarks aimed at mocking the society of the Regency era. Certain customs and situations which are ironical can be unclear for the contemporary reader from both the United Kingdom and Poland. Therefore, reading such a novel requires some specific knowledge not only from the translator, but also from the readers. Translator has to choose between bringing the text closer to the contemporary foreign reader or relying on their knowledge of the famous author and her culture.

The aim of this paper is to analyse Jane Austen's use of irony and its rendering by two Polish translators: Anna Przedpełska-Trzeciakowska and Magdalena GawlikMałkowska, in order to show how particular strategies and techniques can be used to render the implied ironical message and whether they make irony more or less overt. Some of the techniques analysed were found useful by Vallès (2014) in rendering humour. Hejwowski's (2006) techniques for translating cultural aspects are also considered since irony is culture-bound. The differences found in the approaches adopted by the translators answer the question whether these strategies and techniques, used by the translators, can be successfully adopted and whether they preserve the ironical as well as the literal meaning of Jane Austen's text. Irony is the prevailing attitude adopted by the narrator of Pride and Prejudice, hence its importance.

Anna Przedpełska-Trzeciakowska is the author of the first Polish translation of Pride and Prejudice, the first edition of which appeared in 1957, published by Państwowy Instytut Wydawniczy. The translations by Magdalena Gawlik-Małkowska were published by Prószyński Media (earlier: Prószyński i S-ka). The third Polish translator of the book is Katarzyna Surówka. Her version is omitted here, as it is the least popular, published only two times by Zielona Sowa ${ }^{2}$.

\section{Irony as a literary device}

In the broader sense, irony refers to the variety of verbal expressions, as well as to the situations expressed in ways different than verbal (Østergaard 2014: 449). One of the first definitions of this phenomenon was formulated by the ancient Greek philosopher

2 Data presented in the paragraph are taken from the online Catalogues of National Library (Katalog Biblioteki Narodowej, access: 15.08.2020). 
Aristotle (384-322 BC), and described as a person's attitude (an "understatement"); it was adopted for example by Socrates, who used irony while convincing others to his beliefs (Allemann 1986: 228).

Nowadays, scholars look at the phenomenon of irony from different perspectives. Oxford Dictionary distinguishes between a linguistic definition: expressing one's meaning with the use of the words meaning the opposite; figurative meaning: "a state of affairs" contrary to what is expected, which evokes an amused feeling; and a "literary technique" used originally in ancient Greece, when the significance of the character's actions was known to the audience, but not to the character himself (Oxford Dictionary: irony). Irony can be dependent on the speaker performing a certain speech act or on the external factors, so called "fate".

Irony can also be defined simply as "a contrast between reality and appearance" (Khalaf 2017: 70). When the spoken and the written word is concerned, this phenomenon is "an insincere statement, where the speaker intends the listener to perceive it as insincere and where the statement constitutes a misfit with some aspects of the context" (Østergaard 2014: 449). This definition contains one of the main features of irony, namely, insincerity.

Irony is often seen as "the subtlest comic form" (Chowdhury 2007: 9). It is confused with sarcasm and satire; the first being a more obvious, exaggerated (Chowdhury 2007: 9) and aggressive form of irony (Attardo 2000: 795); the second attempting to ridicule human weakness to advocate reform (Chowdhury 2007: 10). The main features of irony are: ambiguity, lack of hurtful aim and lack of moralistic attitude (Chowdhury 2007: 8; Chakhachiro 2009: 33). Irony is also often associated with humour, although it co-exists with tragedy, as well (Chowdhury 2007: 24).

Irony carries emotional values (Attardo 2000: 794). Therefore, it can be positive or negative, although in both cases it is critical since one can pretend to criticise while implicating praise or, more often, pretending to praise while criticising. It is witty, intelligent and always contains a feeling, judgement or attitude of a disapproving kind (Garmendia 2010: 401). Still, it can be jovial (Kaufer 1986:319), as is Jane Austen's irony. As an ironist, she presents a disillusioned albeit sympathetic outlook on human nature and society (Chowdhury 2007: 171-172). In the words of her character Elizabeth she presents her view on that issue:

I hope I never ridicule what is wise or good. Follies and nonsense, whims and inconsistencies, do divert me, I own, and I laugh at them whenever I can (Austen 2004: 57)

Furthermore, the aesthetic value of the ironists' witty remarks is for them of a great importance. When analysing irony as an interpretive form, a significant aesthetic role can be attributed to binary oppositions, which are pairs of mutually-exclusive terms or concepts (Kaufer 1986: 321). In Pride and Prejudice these are, for example, knowledge 
and truth, intentions and expectations, self-perception and the way others see us (Chowdhury 2007: 4-5).

Irony in Pride and Prejudice is humorous, gentle, ridiculing the society, but with no intention of reforming it (Chowdhury 2007: 11, 24, 27, 29). It is implicated in the narrative, but also revealed in the characters' words (Chowdhury 2007: 11, 41). The proper characterization of Austen's use of irony is important in order to preserve its original style in translation.

\section{Translating literary irony}

While translating irony, the key issue is to render the implied ironical message and the narrator's attitude to the world. As Skorov observes:

If an entire book is pervaded by irony, then irony itself is the book's most important message. As a consequence, it is irony that must be, above all, conveyed in the translation of such a book - at the expense, sometimes, of literal accuracy (Skorov 2009: 102).

It can be difficult because the cultural differences occur also on the level of employing and understanding humour and irony (Chakhachiro 2009: 32-33). In Muir's opinion, English humour is "a variety of irony", connected with English free and individualistic culture (see Chakhachiro 2009: 33).

Translating irony requires implication of more strategies than those typically used for translation. The first task is to perceive irony. Grice's conversational maxims can serve as a useful reference here. Grice identifies four maxims that illustrate the assumptions made by listeners, or here: by readers. Irony is often perceived as a violation of the first maxim of quality (Chakhachiro 2009: 43), which states that a speaker should not say what they believe is not true (Grice 1991: 27). Perceiving this violation should make a translator aware that he or she should search for an implicature. An interpretation, however, should be made along with the exploration of the context in which a violation occurs (Chakhachiro 2009: 43-44).

Chakhachiro (2009) claims that translating irony is highly dependent on the translator's interpretation and reformulation. He proposes to consider Nida's notions of formal and dynamic equivalence and Newmark's semantic and communicative translations, for the purpose of translating irony (Chakhachiro 2009: 32). Hutcheon's markers of irony, e.g. questions, understatements, echoic mentions, misrepresentation, pretended advice, euphemism also can be helpful while identifying irony in the text (Hutcheon 1995: 153). It is important to remember that the product of the translation should enable readers to perceive the ambiguity of the original ironical message, that means, literal meaning should be accessible as well as the non-literal one, as according to the indirect negation view theory, irony requires the existence of both literal and implied meanings (Attardo 
2000: 799). Producing a text that lacks the ambiguity of the original can be considered a mistake. Mistakes can occur as a consequence of overused literal forms of translation, erroneous interpretation, wrong realisation of the TT or lack of awareness of the principles of translation (Hejwowski 2006: 125-126).

Chakhachiro, Skorov and many other scholars who examined literary irony for the purpose of translation focus mostly on the irony itself, on perceiving and decoding it. The same can be said about Birkelund. In "Translating the implicit", she carries out an analysis of the existing Danish translations of Pride and Prejudice, focusing on rendering the message implied in the text (Birkelund 2016). After analysing these studies, a conclusion can be drawn that the most important task while translating the implicit message is to perceive it and decode it, determining its meaning in the text.

\section{Translation strategies and techniques}

In her article, Zohre Owji (2013) states that the term "translation strategy" is widely used by the scholars in various contexts and with different meanings. In general, translation strategies are used by the translator when he or she encounters a problem with a literal translation (Owji 2013). Various strategies enable the translator to produce the equivalent text in the target language. Molina and Albir differentiate between the "strategies" that are about finding the way to translate a unit, and "techniques" that are the solutions "materialized", used in practice (Molina \& Albir 2002: 508).

The first to classify translation "procedures" as they called it, were Vinay and Darbelnet (see Molina \& Albir 2002: 499). In their work, Stylistique comparée du français et de l'anglais (1958), they classify them into two broader categories of direct (literal) and oblique (free) translation, and identify more specific procedures accompanying them (Vinay and Darbelnet 1972: 46-54). Another scholar, Nida (1964), proposes three techniques of adjustment: additions, substractions and alternations (Nida 1964: 226-238). He classifies footnotes as an adjustment technique (Nida 1964: 238). Other scholars who deal with translation strategies and techniques are for example: Vázquez Ayora (1977), Newmark (1988), Delisle (1993), Molina and Albir (2002).

The universal models and strategies that enable the analysis and rendering of irony are limited (Chakhachiro 2009: 37). Still, the article will show that many general translation strategies are applicable to the translation of irony, as well. When translation techniques are concerned, especially important will be the classification provided by the Polish scholar Hejwowski, as his techniques are connected with translating cultural aspects of the text. Hejwowski distinguishes:

- Reproduction without explanation - importing the foreign word into the TT. The spelling can be slightly adapted in order to fit the target language;

- Reproduction with explanation - a short explanation is added in order to draw the expression closer to the reader and enable him or her to classify and reconstruct it; 
- Syntagmatic translation without explanation - a literal translation;

- Syntagmatic translation with explanation - a literal translation with explanation enabling readers to understand the meaning of the utterance in the source culture;

- Established equivalent - e.g. the translation of the names of the institutions or of the geographical names;

- Functional equivalent - a name or an allusion to something not widely known in the target culture is changed for a name or an allusion known better;

- Hypernym - using the word of a broader meaning;

- Descriptive equivalent - description or definition is used instead of the word;

- Abandonment - leaving out a certain element (Hejwowski 2006: 76-83).

Hejwowski's techniques are important while translating irony, a cultural phenomenon. Still, due to the space limitation, other strategies and techniques will serve as a basic structure for the analysis of the translations of Pride and Prejudice. These will be:

- Domestication and foreignization

- Substitution of an ironic expression

- Replacement of an expression by an idiom

- Omission

- Correcting original phrase.

Domestication and foreignization are considered to be general strategies adopted by the translators (Hejwowski 2006: 76). Identifying them in the first place will help to perceive the attitude adopted by the translators. The terms were coined by Venuti on the basis of the Schleiermacher's claim that the translator can either move the reader towards the writer (foreignization) or move the writer towards the reader (domestication) (Venuti 1995: 19-21). When the translation of a dated text is concerned, the choice between the archaic and the transparent language can be also mentioned here, as connected with the previous terms (Munday 2008: 144-145). The archaic language will be preferred along with the foreignization, the transparent language - along with the domestication. The issue of the translation of irony makes the choice between the two even more difficult. Irony is highly culture-bound; it exploits stereotypes and social habits that can be obscure to the target reader. Margot claims that there are three cases when the cultural adaptation can be justified: when the certain item is not known in the target culture (then, the classifier can be used), when the background is historical (a linguistic rather than cultural translation is proposed) and when the text should be adopted to the specific situation (Molina \& Albir 2002: 503). The text analysed in this article, Pride and Prejudice, aims to ridicule the English society of the early $19^{\text {th }}$ century, so the translator should preserve the style of the author by using a slightly archaised language and using classifiers in order to explain the meaning or application of certain items of the source culture. 
The techniques following these two strategies: substitution, replacement and omission are identified by Chiaro (2006) and used by Vallès (who calles them "procedures") in his study of the translation of humour (Vallès 2014: 46). The first one is called the substitution of an expression. Original sentence can be substituted partly or wholly in order to fit the TT and preserve its ironic meaning for the TT readers (this specific technique overlaps with the more general strategy of domestication). A sentence can also be replaced by an idiomatic expression of a similar meaning. Where necessary, an ironical expression can be omitted and, to preserve the general tone, can be implied in a different part of the text where originally it did not occur (Vallès 2014: 46).

Vallès (2014: 46) also uses techniques enumerated by Delabastita (1993: 39), which encompass the three already mentioned: paraphrasing (rewording), amplification, explication, reduction, omission or even word-for-word translation. These techniques, although used by Vallès with reference to the humorous text, are important also when the translation of irony is concerned, which is why they will be analysed in this article.

The last case analysed here is correcting the original phrase, which is considered to be a translator's mistake (Lievois \& Schoentjes 2010: 20). It can be found in the Polish translations of Pride and Prejudice.

It is important to remember that the TT should enable readers to perceive the ambiguity of the original ironical message, that means, the literal meaning should be accessible, as well as the non-literal one. Irony should not be explained in the TT, so that the TT readers will have the possibility of noticing and discovering irony themselves. However, as Zabalbeascoa observes, due to the problems connected with rendering humour (and irony) it seems to be rather popular among the translators to explain the humorous parts of the text so that the translations are often more overt than originals (Zabalbeascoa 2005: 9). It usually happens when the irony is verbal, since irony of a particular situation does not pose great difficulty: it is more the matter of plot than language. Verbal irony is more subtle. It can be missed, reduced (as was already mentioned) or even corrected as a writer's mistake (Lievois and Schoentjes 2010: 20). But there are also cases when the translator carries "ironic reading too far" (Booth 1975: 193).

\section{A brief summary of the novel}

Before proceeding to the analysis of the translations, it is useful to briefly describe the novel. Pride and Prejudice is the ironical depiction of the life of gentry at the turn of the $18^{\text {th }}$ and $19^{\text {th }}$ century. The history of the Bennet family is followed: Mrs. Bennet, a narrow-minded woman and a victim of her husband's irony; Mr. Bennet, a private ironist sharing his amusement only with Elizabeth; Jane, the oldest daughter and a sweet-heart; Elizabeth, a witty ironist and the voice of Jane Austen in the novel; Mary, the middle sister, whose pretentions to be seen as well-read and skilled present an 
ironical contrast with her appearance as self-righteous and boring; Kitty and Lydia, the youngest daughters, described as infantile and silly.

When a wealthy bachelor, Mr. Bingley, along with his sisters and his friend, Mr. Darcy, arrive to the neighbourhood, the local girls start thinking about marrying the gentleman. Mr. Bingley and Jane develop interest in each other, while seemingly proud and supercilious Mr. Darcy is attracted to Elizabeth, who dislikes him. Elizabeth's objections regarding Mr. Darcy are stirred by Wickham, an officer, who has been acquainted with Darcy since childhood. Another ironically presented character is Mr. Bennet's cousin, pompous clergyman called Mr. Collins, who arrives with the intention of finding a wife.

The characters encounter troubles and learn that the first impression is often misleading. At the end, three of Mrs. Bennet's daughters marry, which is enough to make the mother happy; Jane and Elizabeth succeed in finding true love: Mr. Bingley and Mr. Darcy.

\section{Study methods}

A close analysis of the texts is carried out, following the order presented above in the bullet point list. The excerpts from the book and its translations are chosen subjectively, in order to match the strategy described, but they are representative of the whole translations. All of the examples contain irony. The excerpts are compared in search for the differences made by the various strategies and techniques which were adopted by the translators.

\section{The analysis of the translation strategies and techniques}

Firstly, the general strategies adopted by the translators will be analysed, followed by a comparative analysis of the particular strategies they used.

\section{Domestication and foreignization}

Table 1. Domestication and foreignization (Example 1)

\begin{tabular}{|c|c|c|}
\hline Austen & Przedpełska-Trzeciakowska & Gawlik-Małkowska \\
\hline $\begin{array}{l}\text { "There is a very fine old saying, } \\
\text { which every body here is of course } \\
\text { familiar with - 'Keep your breath } \\
\text { to cool your porridge,'- and I } \\
\text { shall keep mine to swell my song } \\
\text { (Austen 2004: 25). }\end{array}$ & $\begin{array}{l}\text { - Jest taki stary morat, który } \\
\text { wszyscy dobrze znają: } \\
\text { "Błogostawieni, którzy nie majac } \\
\text { nic do powiedzenia, nie ubieraja } \\
\text { tego w stowa”. Nie powiem już nic } \\
\text { więcej, by oszczędzić tchu na moje } \\
\text { pieśni (Austen 2005: 24). }\end{array}$ & $\begin{array}{l}\text { - [...] Istnieje stare, madre } \\
\text { powiedzenie [...] "Zachowaj } \\
\text { oddech do studzenia owsianki" } \\
\text { Ja oszczędzę swój na me pieśni } \\
\text { (Austen 2012: 24). }\end{array}$ \\
\hline
\end{tabular}


Domesticating strategy can be observed in the translation of a proverb cited by Elizabeth in her witty response to Darcy. The "fine old saying", namely: "Keep your breath to cool your porridge", is explained in The Free Dictionary as "focus on yourself and your life, rather than other people's lives and issues" (Farlex Dictionary of Idioms: keep your breath to cool your porridge). Dictionary.com refers to it as the "idea of not expending one's breath to say something another person doesn't want to hear" (Dictionary.com: save one's breath). The literal meaning already suggests this interpretation: keep your breath in order to use it for your benefit. Elizabeth tries to tell Mr. Darcy that he is wasting his breath talking to her, while she is not going to do the same: she is going to use her voice to sing to the delight of the company. In the wider context, she intends to stop the conversation with Mr. Darcy, as she was asked by her friend to perform a song. But she does not stop it overtly. She tries to suggest to Mr. Darcy that the talk is over. It is possible that she does it with an ironic tone of voice, as the meaning of her sentence seems to be dismissive.

Translating the proverb into Polish is not an easy task. There is no proverb in the target language which would correspond to its meaning. The phrase "save your breath" or "keep your breath" can be translated as "oszczędź sobie” ('spare yourself') or "daruj sobie" ('save it'). This is, however, a very direct and overt statement, rather colloquial. It would not fit the style and manner of the book and the character. The translators, therefore, had to find a proverb that would be the closest to the original meaning, or translate it literally. The first choice carried the risk of losing the coherence of the sentence: if the proverb chosen does not contain the word "breath" or any other referring to the second part of the utterance, then the second part will not fit it. It would have to be changed in order to preserve the reference to the proverb, or left as it is, losing its connection with the proverb.

Gawlik-Małkowska decided on translating the proverb literally (syntagmatic translation without explanation). Although "zachowaj oddech do studzenia owsianki" is not a proverb in the Polish language, its meaning can be deduced from the context. "Porridge" is here translated as "owsianka" ("oat porridge"), so a more general word is translated as a specific one (a hypernym is used). In Poland, oat porridge is a popular simple dish eaten usually for breakfast and the word "porridge" itself has no direct equivalent. What Gawlik-Małkowska did here can be called foreignization. She translated the English proverb literally, uprooting it from its original historical, cultural and language context and using it in this form in the target language. Consequently, the proverb does not belong to the target culture and is not identified as such by the Polish readers. They distinguish it as foreign, even though they are able to understand its meaning.

Przedpełska-Trzeciakowska, on the contrary, decided on using the domesticating strategy and found a Polish equivalent, although not a proverb. The sentence used by her: "Błogosławieni, którzy nie mając nic do powiedzenia, nie ubierają tego w słowa" 
('Blessed are those who, having nothing to say, do not put this into words') has a biblical etymology. Its form is based on the Beatitudes - Biblical blessings, which are familiar to a Polish person, as Polish culture is rooted in Christianity. But it is not the translator who modified the original version of the blessings. Przedpełska-Trzeciakowska paraphrased the words written by a well-known Polish poet, Julian Tuwim: "Błogosławiony ten, co nie mając nic do powiedzenia, nie obleka tego faktu w słowa" ("Blessed is him who, having nothing to say, does not put this fact into words') (Tuwim 1955: 545). It is an ironical parody of the blessings, intending to dismiss the people who talk much, even though they have nothing interesting or important to say. Although Tuwim is wellknown, this particular quotation is not that popular as to be used in everyday language. Przedpełska-Trzeciakowska, using the words of a national poet in lieu of the original proverb, makes them sound familiar, although they are probably recognised more often as a parody of Biblical words, not as the words of Tuwim. Still, Elizabeth paraphrasing Tuwim can be perceived as an erudite. The only problem here is that, strictly speaking, Tuwim was born in 1894, 81 years after Pride and Prejudice was published. Leaving those details behind, it is true to say that Przedpełska-Trzeciakowska succeeded in rendering the proverb, making use of the domesticating strategy and putting the words in the national, Polish context, understandable to the target readers. The translated sentence is still ironic and can be interpreted as dismissive.

Table 2. Domestication and foreignization (Example 2)

\begin{tabular}{|c|c|c|}
\hline Austen & Przedpełska-Trzeciakowska & Gawlik-Małkowska \\
\hline $\begin{array}{l}\text { It was next to impossible that } \\
\text { their [Catherine and Lydia's] } \\
\text { cousin should come in a scarlet } \\
\text { coat, and it was now some weeks } \\
\text { since they had received pleasure } \\
\text { from the society of men in any } \\
\text { other colour (Austen 2004: } 65 \text { ). }\end{array}$ & $\begin{array}{l}\text { Nie byto możliwe, by kuzyn } \\
\text { ich [Katarzyny i Lidii] pojawit } \\
\text { się } w \text { szkartatnym wojskowym } \\
\text { mundurze, a od wielu tygodni } \\
\text { nie znajdowaty przyjemności } \\
\text { w towarzystwie męzczyzn w } \\
\text { ubraniu innej barwy (Austen } \\
\text { 2005: 58). }\end{array}$ & $\begin{array}{l}\text { Prawdopodobieństwo, że kuzyn } \\
\text { [Catherine i Lydii] przyjedzie w } \\
\text { szkartatnym mundurze, graniczyło } \\
\text { z cudem, a od paru tygodni ich } \\
\text { aprobatę zyskiwali wytacznie } \\
\text { mężczyzni w stroju tej wtaśnie } \\
\text { barwy (Austen 2012: } 57 \text { ). }\end{array}$ \\
\hline
\end{tabular}

Another example contains the element that can be perceived as a part of the English culture. Scarlet coat was a part of the soldiers' regimentals. In Poland a coat of this colour carries the connotations with the kings or rulers, not soldiers. In the excerpts presented in Table 2, however, the object of Catherine and Lydia's interest are the soldiers. The narrator ironically states that Mr. Collins' forthcoming visit was of no appeal for the youngest Bennet ladies, as the only men they were interested in were the soldiers who were stationed in the nearby town at the time. What is ridiculed here is the girls' affection for soldiers, which can be called superficial, based only on their appearance and 
the charm of their occupation, simply speaking: their "colour". Colour plays an important role here and, in the source language it helps the readers to identify the men as soldiers. Gawlik-Małkowska translated this phrase literally (syntagmatic translation without explanation) as "szkarłatny mundur" ('scarlet coat'), relying on the readers' knowledge of whom the colour indicated. Reading the novel, the reader is familiar with the sisters' choices concerning men, therefore the explanation may not seem necessary. Still, Przepełska-Trzeciakowska decided to add the adjective "wojskowy" ('military'), while preserving the colour of the coat in the translation (syntagmatic translation with explanation). The phrase "szkarłatny wojskowy mundur” ('scarlet military coat') clearly specifies the kind of men that caught Catherine and Lydia's attention, still describing a part of British regimentals. Both of the translators chose the strategy of foreignization here. Nonetheless, Przedpełska-Trzeciakowska made an attempt to "move the writer towards the reader" and facilitate understanding the phrase.

Przedpełska-Trzeciakowska tends to produce more literal translation, while GawlikMałkowska paraphrases the original. What can be observed here, on a side note, is Przedpełska-Trzeciakowska's domesticating strategy with translating names, while Gawlik-Małkowska preserved the foreign spelling.

Table 3. Archaisation (Example 3)

\begin{tabular}{|l|l|l|}
\hline \multicolumn{1}{|c|}{ Austen } & Przedpełska-Trzeciakowska & \multicolumn{1}{|c|}{ Gawlik-Małkowska } \\
\hline $\begin{array}{l}\text { To be fond of dancing was a } \\
\text { certain step towards falling in } \\
\text { love; and very lively hopes of Mr. } \\
\begin{array}{l}\text { Bingley's heart were entertained } \\
\text { (Austen 2004: 11). }\end{array}\end{array}$ & $\begin{array}{l}\text { Jeśli znajduje przyjemność } w \\
\text { tańcu, to, oczywista, tatwo mu } \\
\text { przyjzie się zakochać. Wszystko } \\
\text { to krzepito nadzieje w sercu pani } \\
\text { Bennet (Austen 2005: 11). }\end{array}$ & $\begin{array}{l}\text { Taniec dzielit przeciez od zakochania } \\
\text { tylko krok, i niejedna panna miata } \\
\text { nadzieje zdobędzie serce pana } \\
\text { Bingleya (Austen 2012: 11). }\end{array}$ \\
\hline
\end{tabular}

The strategy of archaisation, connected with the strategy of foreignization, can be noticed in the two translations, although Gawlik-Małkowska tends to use more fluent and contemporary language. The example of using rather archaic words occurs in Przedpełska-Trzeciakowska's translation presented in Table 3. The example from the novel regards the hopes that aroused after Mr. Bingley had declared coming to the next assembly in the neighbourhood. The ladies who were looking for a husband, as well as Mrs. Bennet, who was eager to get her daughters engaged, gave this piece of news more emphasis than it deserved. They expected dance to lead to a romance and, consequently, to a wedding. In these words, the narrator echoes and ridicules the contemporary society's way of thinking and the attitude towards romance and husband-seeking. The use of archaic or modern words does not change the overall ironic tone of the excerpt, but it is helpful while identifying the time of the events. The chosen fragments are also 
representative of the strategies used by the translators in this context. PrzedpełskaTrzeciakowska uses archaic words to render Jane Austen's sentences: "certain" is translated as "oczywista", where it would be more natural to say "oczywiście" in present-day Polish. "Krzepiło nadzieję" ('got (her) hopes up') is also rather literary and oldfashioned. The language, however, is certainly more contemporary than it would have been, had Pride and Prejudice been rendered in the times when it was first published in the original. Gawlik-Małkowska, in her turn, used modern and natural language here and made the sentence shorter, rendering the sense rather than the original syntax. This example is representative of the whole approach of Gawlik-Małkowska to the translation of the novel.

To sum up, Przedpełska-Trzeciakowska uses a rather archaic language, but makes use of the domesticating strategy, in order to bring the source culture closer to the Polish readers. She uses syntagmatic translation with explanation and the adjustment technique of footnotes (not presented here) so she is also trying to preserve the original elements, but in a way that will be understandable for the reader. Gawlik-Małkowska's translation is more precise, moderately modernised. She preserves the original elements using syntagmatic translation without explanation, but she also uses hypernyms in order to make certain expressions more understandable.

\section{Substitution of an ironic expression}

Table 4. Substitution (Example 4)

\begin{tabular}{|c|c|c|}
\hline Austen & Przedpełska-Trzeciakowska & Gawlik-Małkowska \\
\hline $\begin{array}{l}\text { To be sure it would have been for } \\
\text { the advantage of conversation, } \\
\text { had Miss Lydia Bennet come } \\
\text { upon the town; or, as the happiest } \\
\text { alternative, been secluded from the } \\
\text { world, in some distant farm-house } \\
\text { (Austen 2004: 299). }\end{array}$ & $\begin{array}{l}\text { Prawde mówiac, rozmowy w } \\
\text { salonach bytyby o wiele ciekawsze, } \\
\text { gdyby panna Lidia Bennet } \\
\text { przeszła na utrzymanie parafii lub } \\
\text { gdyby - w najlepszym wypadku } \\
\text { - trzymano ja do końca zycia w } \\
\text { zamkniecciu na jakiejś odlegtej } \\
\text { farmie (Austen 2005: 249). }\end{array}$ & $\begin{array}{l}\text { [Sasiedzi] [b]yliby zapewne } \\
\text { bardziej przejęci, gdyby Lydia } \\
\text { powrócita do domu panna lub- } \\
\text { jeszcze lepiej-zostata skazana } \\
\text { na pustelniczy żywot na jakimś } \\
\text { odludziu (Austen 2012: 241). }\end{array}$ \\
\hline
\end{tabular}

An interesting example of the substitution of an ironic expression in the analysed translations of Pride and Prejudice is the case presented in Table 4. The excerpts describe Lydia's return, after she escaped with Wickham, and the couple were found and persuaded to marry. Lydia came home as a married woman, but the marriage was preceded by a scandal. The narrator tries to ridicule the small community's quest for gossip, the more scandalous, the better. Narrator ironically suggests that the news about Lydia's 
return were not dramatic enough, therefore the gossip was too boring. The event would have been more appealing for the neighbours if something more remarkable and tragic had happened to Lydia.

In the original sentence, Austen uses the euphemism "come upon the town", which, according to the footnote in the quoted edition of the novel, means "become a prostitute" (Austen 2004: 299). The narrator suggests that if Lydia had become a prostitute, instead of marrying a soldier, the news would had been more interesting. Jane Austen's humour is well-manifested here. It is witty and bold in exposing the small community's weaknesses, even if she used a euphemism in order to convey the intended message.

Euphemism can be called one of the stylistic devices that convey irony (Skorov 2009: 92). The use of it should make the reader aware that an ironic intention can be implied by it. The euphemism is, however, archaic, therefore its meaning could have been misunderstood, missed or changed intentionally. Regardless of the reason, both the translators decided on substituting the phrase. Przedpełska-Trzeciakowska translated it as "przeszła na utrzymanie gminy" ('started being supported by parish'). The meaning of this phrase is rather obscure for the modern reader. In the 19th century, parishes were obliged to take care of the poor of their area (Mitchell 2009: 91). PrzedpełskaTrzeciakowska's phrase means that Lydia became poor, maybe excluded from her family. The original meaning is removed, but the sentence can be still perceived as ironic. Therefore, the irony is conveyed not only by the euphemism, although its use is helpful while identifying the implicature. Still, the intention to ridicule the community is visible regardless of the dramatic events that are perceived as more interesting for the gossiping neighbours. The translated phrase, however, does not have any connotations with an occupation that can be considered as taboo. The humour, therefore, is less daring.

Gawlik-Małkowska replaces the examined phrase with "powrócić do domu panną" ('come back home as a maiden'), which carries a meaning opposite to both being a prostitute (as in the original) and being a married woman (which is what really happened to Lydia in the novel). As the opposite to the events from the book, it creates a contrast, which can be perceived by the reader as ironical. Moreover, it suits the context. It would have been scandalous, if Lydia had come back without the man with whom she escaped. The cited phrase is no longer a euphemism and lacks the taboo connotations, still, the ironic implication is visible. Therefore, the strategy of substituting the original phrase can be successfully used, even though the literal meaning is not preserved. Still, the original allusion in the example analysed was in some aspects weakened. 


\section{Replacement of an expression by an idiom}

Table 5. Replacement of an expression by an idiom (Example 5)

\begin{tabular}{|c|c|c|}
\hline Austen & Przedpełska-Trzeciakowska & Gawlik-Małkowska \\
\hline $\begin{array}{l}\text { "In point of composition" said } \\
\text { Mary, "his letter does not seem } \\
\text { defective. The idea of the olive } \\
\text { branch perhaps is not wholly new, } \\
\text { yet I think it is well expressed." } \\
\text { (Austen 2004: 65). }\end{array}$ & $\begin{array}{l}\text { - Z punktu widzenia kompozycji - } \\
\text { wtracita Mary - list ten nie wydaje } \\
\text { się btędny. Pomyst z gatazka } \\
\text { oliwna nie jest może zupetnie } \\
\text { nowy, ale tu znalazt się, moim } \\
\text { zdaniem, bardzo na miejscu } \\
\text { (Austen 2005: } 57 \text { ). }\end{array}$ & $\begin{array}{l}\text { - W kwestii kompozycji - } \\
\text { powiedziata Mary - jego list } \\
\text { wydaje się bez zarzutu. Idea } \\
\text { niesienia gatazki oliwnej zapewne } \\
\text { traci myszka, lecz moim zdaniem } \\
\text { zostata wyrazona jak należy } \\
\text { (Austen 2012: 57). }\end{array}$ \\
\hline
\end{tabular}

The cited example may not be the most suitable, but it clearly illustrates the strategy of the replacement of an expression by an idiom. It is not the most suitable in the case of representing the translation of irony, since the choice of the phrases here does not influence the reader's perception of the character described. The irony here is situational: Mary comments on the pompous letter written by Mr. Collins, a thoroughly humorous character ridiculed by the narrator, as well as by the witty characters in the novel (Lizzy and her father). While the mentioned characters, Elizabeth and Mr. Bennet, do not seem to treat the letter and their author seriously, Mary analyses the writing and comments on its language. Mary tries to come across as intelligent and knowledgeable, while her family does not pay attention to the form of the letter, but to the character and intentions of its sender. Her words are, therefore, shallow and stilted.

Mary comments on one of the expressions used by Mr. Collins: on the phrase "olive branch". He used it probably with the same intention with which Mary shares her comments: in order to come across as intelligent and erudite. She calls this phrase "not wholly new", even though she approves of its use in the context. Mary's simple words are translated by Gawlik-Małkowska with an idiom understood nowadays, but made up of semantic archaisms: "trącić myszką". The meaning of the idiom is the same as of the original phrase, therefore it does not change the literal meaning of the sentence. Mary's use of the idiom, however, strengthens the pompous character of her words, as they sound less natural in everyday speech. In Gawlik-Małkowska's translation, Mary's words are even more misplaced than in the original and the irony of the situation is more visible.

Przedpełska-Trzeciakowska's translation is also presented here, but it will not be analysed, since she used the literal translation. The only reason for placing them both in the table is to enable the comparison. It also enables perceiving the subtle difference in the tone of Mary's utterance, based on the chosen translations of the phrase analysed. 


\section{Omission}

Table 6. Omission (Example 6)

\begin{tabular}{|l|l|l|}
\hline \multicolumn{1}{|c|}{ Austen } & Przedpełska-Trzeciakowska & \multicolumn{1}{|c|}{ Gawlik-Małkowska } \\
\hline $\begin{array}{l}\text { [...] the young ladies [...] were } \\
\text { usually tempted tither three or four } \\
\text { times a week, to pay their duty } \\
\text { to their aunt, and to a milliner's } \\
\text { shop just over the way (Austen } \\
\text { 2004: 29). }\end{array}$ & $\begin{array}{l}\text { [..] co najmniej trzy razy w } \\
\text { tygodniu, znęcone ciekawościa i } \\
\text { pokusa drobnych zakupów, szty } \\
\text { zwizyta do ciotki i modniarki, } \\
\text { której sklep wypadat im po drodze } \\
\text { (Austen 2005: 27). }\end{array}$ & $\begin{array}{l}\text { [...] bywaty tam trzy lub cztery } \\
\text { razy wygodniuz wizyta u ciotki } \\
\text { oraz zagladaty do znajdujacego sie } \\
\text { po drodze sklepu modystki (Austen } \\
\text { 2012: 27). }\end{array}$ \\
\hline
\end{tabular}

The translator can also omit an ironical expression. It can be compensated later by adding an ironical expression where it does not originally occur. The ironic meaning of the expression was for instance left aside by Gawlik-Małkowska, as the example in Table 6 illustrates. Meryton was a nearby town, where an aunt of the Bennet daughters lived. The narrator ironically states that Kitty and Lydia visited the town to see their aunt, and the other kinds of entertainment, for example shopping, were only a bonus. In fact, it was obvious that visiting the aunt was merely an excuse, and the bonuses were the main reason for the girls' trips.

Przedpełska-Trzeciakowska's translation suggests, equivalently to the original sentence, that the "milliner's shop" ('sklep modniarki') was only an interesting stop on the way to the aunt's house. The translator, however, as if trying to make the motives of the young Bennets clear for the reader, adds the information (amplification technique) that they were tempted to visit Meryton by their curiosity and the prospect of shopping: "znęcone ciekawością i pokusą drobnych zakupów”. By interposing this piece of information, Przedpełska-Trzeciakowska exempts readers from making their own judgement on the Bennets' behaviour and intentions. The ironical tone of the sentence is therefore weakened, as the reason for the girls' trips is overtly stated and the internal contradiction of the utterance is less visible.

In Gawlik-Małkowska's translation the ironical statement is reduced to simple information. Girls visited their aunt and, on their way to her house, they visited the milliner's shop. The sentence is not ironical, as there is no implied meaning here - the ironical sentence is omitted and it no longer conveys a subtle judgement of the Bennet sisters' character and behaviour. The narrator, therefore, is not ironizing here, as he or she does in the original. 


\section{Correcting original phrase}

Table 7. Correcting original phrase (Example 7)

\begin{tabular}{|c|c|c|}
\hline Austen & Przedpełska-Trzeciakowska & Gawlik-Małkowska \\
\hline $\begin{array}{l}\text { "Why, I must confess that I love him } \\
\text { [Darcy] better than I do Bingley. } \\
\text { I am afraid you will be angry." } \\
\text { (Austen 2004: 361). }\end{array}$ & $\begin{array}{l}\text { - No więc... przyznam ci się, } \\
\dot{z} \text { e kocham go bardziej niż ty } \\
\text { swojego narzeczonego. Boję } \\
\text { się, że się będziesz gniewać } \\
\text { (Austen 2005: 301). }\end{array}$ & $\begin{array}{l}\text { - Boje się, że będziesz zła. Musze } \\
\text { wyznać, że kocham go bardziej niż } \\
\text { Bingleya (Austen 2012: 291). }\end{array}$ \\
\hline
\end{tabular}

The last case mentioned involves the correcting of the original phrase. It is not a desirable situation, as the translator does not perceive the irony, interprets the original phrase as being wrongly formulated and decides to correct it. Hence, an ironical expression is amended and may lose its original implicated meaning. Such a case can be found in Przedpełska-Trzeciakowska's translation. Example presented in Table 7 is Elizabeth's confession made to her sister, Jane. They converse about Elizabeth's surprising decision to marry Mr. Darcy. Jane does not know how Mr. Darcy succeeded in gaining Elizabeth's respect and feelings and is sure she disliked him. She expresses surprise and tries to question Lizzy in order to be sure, whether her sister really loves the man she agreed to marry. During the conversation, Elizabeth playfully assures Jane that she really has feelings for Mr. Darcy. In the source text, Elizabeth tells Jane that her feelings for Darcy are stronger than what she feels for Bingley. Since Elizabeth is supposed to marry Darcy and Jane is engaged to Bingley, this is the normal and expected state of affairs. However, Elizabeth suggests that this confession can make Jane angry. Elizabeth probably makes an ironical reference to Jane's great love for Bingley. She is "afraid" that her sister expects her to also admire Bingley, and being in love with Darcy can come across as insulting - Darcy is considered to be an unpleasant gentleman by the whole Bennet family. This assumption is, of course, absurd. Elizabeth enjoys prolonging the tension with ironical remarks, before she decides to reveal the truth to her sister (the truth about Mr. Darcy's virtues which she discovered in his character). The utterance is meant to annoy Jane, while Elizabeth is clearly enjoying the situation, when she knows the truth and her sister is puzzled.

Przedpełska-Trzeciakowska probably perceived the unusualness of Elizabeth's statement and decided on correcting it. Instead of focusing on Elizabeth's feelings, she decided to make a comparison between both of the sisters and the amount of their love for their fiancés: "kocham go bardziej niż ty swojego narzeczonego" ('I love him more than you love your fiancé'). Elizabeth seems to playfully compete with her sister, at the same time assuring her that she loves Mr. Darcy and that her feelings are stronger than 
Jane's. It can be perceived as underestimating her sister's bond with her fiancé, but when it is analysed as a humorous remark, it cannot be considered derogatory. Indeed, this statement is also humoristic and seems more logical. Still, Jane Austen was supposedly aware of her use of words and the implicatures they hold. Therefore, amending the original text does not seem necessary.

Gawlik-Małkowska's translation will not be analysed here, as it is a literal translation and preserves the meaning of the sentence: "kocham go bardziej niż Bingleya" ('I love him more than I do Bingley'), leaving it to the reader to comprehend this seemingly obvious statement.

\section{Conclusions}

It is a challenge to render irony in Pride and Prejudice. Irony needs to be preserved in its omnipresence in the novel, but it is dated and highly culture-bound. Still, the Polish translators succeeded in converting an ironical tone of Pride and Prejudice for the target readers to notice. A detailed analysis of their translations reveals how different approaches they adopted and how differently they interpreted various passages. Anna Przedpełska-Trzeciakowska's translation is more literal and archaic. She used the strategy of foreignization, but to a limited extent. In comparison with the other translation, Przedpełska-Trzeciakowska more often made attempts to explain certain aspects of the source culture. Still, she enabled a reader to perceive its foreigness and historical context. Magdalena Gawlik-Małkowska made her translation more precise and contemporary. Some aspects of the source culture are preserved here without being explained. The ironical message connected with the cultural aspects is therefore more covert. The techniques enumerated by Delabastita (1993) and those identified by Hejwowski (2006) could be found in both translations, along with the strategies of foreignization and domestication. They were succesfully adopted to translate irony. The particular technique used by the translators did not determine the ironical meaning of the utterance, as long as the irony was perceived and preserved, but it influenced the overtone of the utterance. Irony can be preserved as long as the translated text has both the silent and the implied meaning. It cannot be too overt, since the reader has to discover the irony himself or herself, in order to truly appreciate it.

\section{References}

Allemann, B. 1986. O ironii jako o kategorii literackiej. Pamiętnik Literacki: czasopismo kwartalne poświęcone historii i krytyce literatury polskiej 77: 227-242.

Attardo, S. 2000. Irony as relevant inappropriateness. Journal of Pragmatics 32: 793-826.

Austen, J. 2004. Pride and Prejudice. New York: Barnes \& Noble. 
Austen, J. 2005. Duma i uprzedzenie. Warszawa: Hachette Polska. [translated by Anna Przedpełska-Trzeciakowska]

Austen, J. 2012. Duma i uprzedzenie. Warszawa: Prószyński i S-ka. [translated by Magdalena Gawlik-Małkowska]

Baker, M. 1992. In Other Words: A Coursebook on Translation. London: Routledge.

Birkelund, M. 2016. Translating the implicit. In: S. Vikner, H. Jørgensen \& E. van Gelderen (eds.), Let us have articles betwixt us: Papers in Historical and Comparative Linguistics in Honour of Johanna L. Wood, 111-128. Aarhus: Department of English - School of Communication and Culture - Aarhus University.

Booth, W. C. 1975. A Rhetoric of Irony. Chicago/London: The University of Chicago Press. Chakhachiro, R. 2009. Analysing irony for translation. Meta: Journal des traducteurs 54: 32-48.

Chiaro, D. 2006. Verbally expressed humour on screen: Reflections on translation and reception. JOSTRANS: The Journal of Specialised Translation 6: 198-208.

Chowdhury, P. K. R. 2019. Jane Austen the novelist as an ironist. [Unpublished PhD thesis], University of North Bengal, Siliguri. http://hdl.handle.net/10603/148114 (3 February 2019).

Delabastita, D. 1993. There's a Double Tongue: An Investigation Into the Translation of Shakespeare's Wordplay, with Special Reference to Hamlet. Amsterdam: Rodopi.

Garmendia, J. 2010. Irony is critical. Pragmatics \& Cognition 18: 397-421.

Grice, P. 1991. Studies in the Way of Words. Cambridge/London: Harvard University Press.

Hejwowski, K. 2006. Kognitywno-komunikacyjna teoria przekładu. Warszawa: Wydawnictwo Naukowe PWN.

Hutcheon, L. 1995. Irony's Edge: The Theory and Politics of Irony. London/New York: Routledge.

Jakobson, R. 1959. On Linguistic Aspects of Translation. https://web.stanford.edu/ eckert/ PDF/jakobson.pdf (09 March 2021).

Kaufer, D. S. 1986. Ironia, forma interpretacyjna i teoria znaczenia. Pamiętnik Literacki: czasopismo kwartalne poświęcone historii i krytyce literatury polskiej 77: 315-326.

Khalaf, L. 2017. Irony and feminism in Jane Austen's novel Pride and Prejudice. International Journal of English Research 3: 70-73.

Lievois, K., \& Schoentjes, P. 2010. Traduire l'ironie. Linguistica Antverpiensia 9: 11-23.

Mitchell, S. 2009. Daily Life in Victorian England. Wesport, Connecticut/London: Greenwood Press.

Molina, L. \& Albir, A. H. 2002. Translation techniques revisited: A dynamic and functionalist approach. Meta: journal des traducteurs / Meta: Translators' Journal 47: 498-512.

Munday, J. 2010. Introducing Translation Studies. Theories and Applications. London/New York: Routledge. 
Nida, E. 1964. Toward a Science of Translating: With Special Reference to Principles and Procedures Involved in Bible Translating. Leiden: E.J. Brill.

Owji, Z. 2013. Translation strategies: A review and comparison of theories. Translation Journal 17. https://translationjournal.net/journal/63theory.htm (24 August 2020).

Østergaard, S. 2014. The definition and processing of irony. Not published in a journal. https://www.sdu.dk/-/media/files/om_sdu/institutter/isk/forskningspublikationer/ rask/rask+40/oestergaard.pdf (20 November 2020).

Skorov, P. 2009. Translating literary irony: Elements for a practical framework. Vertimo Studijos 2: 88-103.

Tuwim, J. 1955. Jarmark rymów. In: Dzieła. Warszawa: Czytelnik.

Vallès, D. 2014. Applying Juliane House’s Translation Quality Assessment Model (1997) on a humorous text: A case study of "The Simpsons". New Readings 14: 42-63.

Venuti, L. 2008. The Translator's Invisibility: A History of Translation. London/New York: Routledge.

Vinay, J. P. \& Darbelnet, J. 1972. Stylistique Comparée du Français et de L’Anglais: Méthode de Traduction. Paris: Didier.

Wilson, D. \& Sperber, D. 2012. Meaning and Relevance. Cambridge: Cambridge University Press.

Zabalbeascoa, P. 2005. Humor and translation, an interdiscipline. Humor - International Journal of Humor Research 18: 185-207.

\section{Web pages:}

Web 1 - Irony. https://en.oxforddictionaries.com/definition/irony (19 December 2018).

Web 2 - Keep your breath to cool your porridge. https://idioms.thefreedictionary.com/ke ep+your+breath+to+cool+your+porridge (24 August 2020).

Web 3 - Save one's breath. https://www.dictionary.com/browse/save-one-s-breath (24 August 2020).

\section{$* * *$}

Magdalena Żochowska is a graduate of Philology, English in business and translation at Siedlce University of Natural Sciences and Humanities, Poland. She is nearing completion of her Master's Degree in Journalism and Social Communication, and in English Studies. Her research interests include 19th-century literature and its translations as well as readers' self-representation in social media. 